\title{
Blockade of Treg derived TGF- $\beta$ abrogates suppression of effector $T$ cell function within the tumor microenvironment
}

\author{
Sadna Budhu', David Schaer ${ }^{1 *}$, Yongbiao Li ${ }^{1}$, Alan Houghton', Samuel Silverstein ${ }^{3}$, Taha Merghoub $^{1,2}$, \\ Jedd Wolchok ${ }^{1,2}$
}

From Society for Immunotherapy of Cancer 28th Annual Meeting

National Harbor, MD, USA. 8-10 November 2013

Regulatory T cells (Treg) play a role in suppression of anti-melanoma immunity; however, the exact mechanism is poorly understood. Through intravital two photon microscopy, we found that Pmel-1 effectors engage in cell-cell interactions with tumor resident Tregs. To determine if contact between Tregs and $\mathrm{T}$ effectors (Teff) hinders killing of tumor cells in vivo, we utilized ex-vivo three-dimensional collagen-fibrin gel cultures of B16 melanoma cells. Collagen-fibrin gel cultures recapitulated the in vivo suppression, rendering the dissociated tumor resistant to killing by in vitro activated antigen specific Teff. In vivo depletion of Tregs in foxp3-DTR mice prior to tumor excision reversed the suppression. Additionally, In vivo modulation of intra-tumor Tregs suppressive function by GITR ligation had a similar effect, leading to ex-vivo tumor killing. Using neutralizing antibodies, we found that blocking TGF- $\beta$ reversed the suppression. In addition, soluble factors from collagen-fibrin gel tumors do not inhibit killing suggesting that suppression is contact or proximity dependent. The CD8 Teff recovered from these gels exhibit a decrease in Granzyme B expression and an increase in expression of $\mathrm{T}$ cell exhaustion marker PD-1. These findings support the conclusion that intra-tumor contact with Tregs during the effector phase of the immune response is responsible for inhibiting anti-melanoma immunity in a TGF- $\beta$ dependent manner, elucidating a novel way to target intratumoral Tregs.

\section{Authors' details}

'Immunology, MSKCC, New York, NY, USA. ${ }^{2}$ Medicine, MSKCC, New York, NY, USA. ${ }^{3}$ Columbia University, New York, NY, USA.

Published: 7 November 2013

doi:10.1186/2051-1426-1-S1-P173

Cite this article as: Budhu et al:: Blockade of Treg derived TGF- $\beta$ abrogates suppression of effector T cell function within the tumor microenvironment. Journal for ImmunoTherapy of Cancer 2013 1(Suppl 1): P173.
Submit your next manuscript to BioMed Central and take full advantage of:

- Convenient online submission

- Thorough peer review

- No space constraints or color figure charges

- Immediate publication on acceptance

- Inclusion in PubMed, CAS, Scopus and Google Scholar

- Research which is freely available for redistribution

Submit your manuscript at www.biomedcentral.com/submit
C Biomed Central 